\title{
OCTOBLEPHARUM POCSII, SP. NOV. A FRAGILE- AND LONG-LEAVED SPECIES IN THE $O$. ALBIDUM - COMPLEX FROM AFRICA
}

\author{
Robert Magill \& BRUCE Allen
}

\begin{abstract}
Octoblepharum pocsii (Calymperaceae) is described from Mount Nimba in Guinea, Africa. It is distinguished by very long, fragile leaves, 8 peristome teeth, small spores and growth on soil.
\end{abstract}

Key words: Octoblepharum, Calymperaceae, Africa, Guinea, Mount Nimba

Robert Magill \& Bruce Allen, Missouri Botanical Garden, P.O. Box 299, St. Louis, MO 63166-0299, U.S.A.; e-mail: bob.magill@ mobot.org \& bruce.allen@mobot.org

\section{INTRODUCTION}

There are noteworthy benefits to collecting bryophytes on different continents: ability to recognize widely distributed taxa; greater skill in identifying new collections; and the ability to note characteristics common elsewhere but unusual in the currently studied flora. These all played a part in the recognition of a new species of Octoblepharum from Africa. On a recent collecting trip to Mount Nimba, Guinea the junior author found an exceptional specimen of Octoblepharum with very fragile, long-leaves growing on a stream bank in uncut forest at the base of the Mount Nimba Strict Nature Reserve. In the field the specimen had an aspect nearly identical to the American species, O. pulvinatum (Dozy \& Molk.) Mitt. (see Allen 1994). It was further similar to O. pulvinatum in its long, fragile leaves and in having leucocysts in 3-4 rows. The African specimen differed in having longer leaves (10-13 vs. 5-9 mm long); lacking any tinge of pink at the base of the leaves; and in having eight rather than 16 peristome teeth.

Africa is thought to be particularly depauperate in species of Octoblepharum. At present there are three species known from continent: $O$. africanum (Broth.) Cardot (Madagascar); O. leptoneuron Cardot (Senegal); and the widespread O. albidum Hedw. Octoblepharum africanum is considerably smaller than the Mt. Nimba plants with leaves only
$4.5 \mathrm{~mm}$ long. Octoblepharum leptoneuron has not been seen since it was first collected. Its original description is starkly non-informative, but it appears to be a small species, and may not even be an Octoblepharum. On the basis of its 8 peristome teeth the Mt. Nimba collection clearly belongs in the albidum-complex, and this is additionally supported by characteristics of the leaf shape, apex and anatomy (see Magill 1981).

The type of $O$. albidum is from Jamaica. In the Neotropics the species is stenotype with small plants that have firm, non-fragile leaves only 3-8 mm long. Our preliminary examination of African material of Octoblepharum indicates the genus is much more diverse than is presently recognized and there has been an unfortunate tendency to assign all collections of Octoblepharum with eight peristome teeth to $O$. albidum ignoring the variation in plant size, anatomy and habitat that seems to exist.

The literature hints at the occurrence of other long-leaved specimens of Octoblepharum in central Africa. Raymond Naveau (1927) refers to two of his specimens (3217 and 1783) collected in forests of Zaire in 1914 under the name O. albidum with the additional annotation 'forma longifolia Dixon' but without a description or illustration. This name was used by other authors, e.g., 


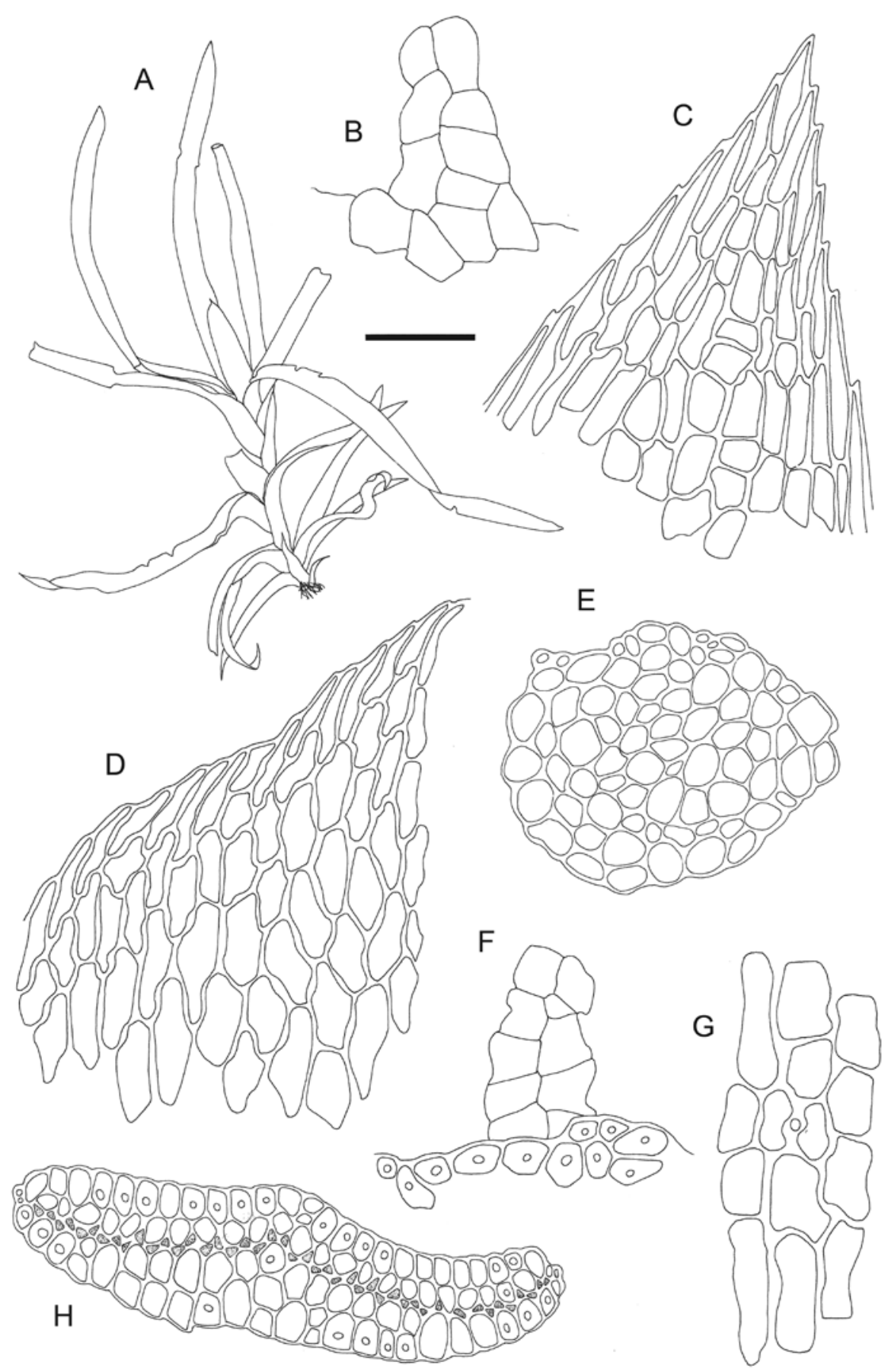

Fig. 1. Octoblepharum pocsii R. E. Magill \& B. H. Allen, sp. nov. A - habit, B - peristome tooth, ventral (inner) surface, $\mathrm{C}$ - leaf apex, D - marginal leaf sheath cells, E - stem in cross section, F - peristome tooth, dorsal (outer) surface, $\mathrm{G}$ - stomata, $\mathrm{H}$ - leaf in cross section. Scale in mm: bar $=0.05(\mathrm{~B}, \mathrm{~F}, \mathrm{G})$; bar $=0.06(\mathrm{E})$; bar $=0.07(\mathrm{C}, \mathrm{D})$; bar $=0.13(\mathrm{H})$; bar $=3.2(\mathrm{~A})$. All from Allen 30658 (MO, holotype). 
Demaret (1940) and Born et al. (1993), but with no additional information, specimens, or a description added. It is clear that a more careful review of the African specimens of Octoblepharum is required to evaluate this variation before the matter of species composition on the continent can be resolved.

In addition to the morphological characteristics described below the Mt. Nimba specimens were collected on soil along a small stream running through an uncut forest at the base of Mt. Nimba. Octoblepharum albidum does indeed occur in the area, but is typically collected on bark, logs or occasionally rock crevices; we have not seen indication of specimens on soil banks.

There are several Neotropical species of Octoblepharum with very long, fragile leaves, but all differ from the Mt. Nimba collection in having 16 peristome teeth. We believe the Mt. Nimba collection represents a new species and take this opportunity to name it in honor of Tamás Pócs in recognition of his significant contribution to African bryology.

\section{TAXONOMY}

Octoblepharum pocsii Magill \& B. H. Allen, sp. nov.

Fig. 1

TYPE: GUINEA, Nzérékoré, Lola, Mount Nimba Strict Nature Reserve, Along lower Zié River, on stream bank. $07^{\circ} 42^{\prime} 53^{\prime \prime} \mathrm{N} 008^{\circ} 21^{\prime} 41^{\prime \prime} \mathrm{W}$. Allen 30658, 9 July 2012 (HOLOTYPE: MO, ISOTYPE: EGR, HNG).

New species similar to O. albidum Hedw. but differing in its much longer, fragile leaves with consistently more layers of quadrate to very short rectangular leucocysts, and smaller spores.

Plants large, in loose tufts, glaucous green, on soil and rock. Stems short, $0.5-1.5 \mathrm{~mm}$ high, unbranched, in section round, cells uniform, in 8 rows, thin-walled, red-brown, central strand absent. Leaves long lingulate, reflexed above oval base, 10-13 mm long, acute; margins plane, smooth below, weakly serrulate at apices; limbidia inconspicuous in base, cells rectangular, unistratose, 2-3 cells wide, thin walled; basal laminal cells large, short rectangular, thin walled, in section basal lamina unistratose toward margin, becoming bistratose internally, central basal lamina multistratose, 4-7 layers of leucocysts surrounding chlorocysts, leucocysts in 2 rows ventrally, 4-5 dorsally, chlorocysts quadrate or triangular at base; lamina at midleaf with 6 layers of leucocysts surrounding central, alternating rows of triangular chorocysts; distally leucocyst in 4(-5) layers.

Autoicous. Perigonia bud-like, axillary; perigonial leaves ovate apiculate and irregularly prorate marginally; perichaetia terminal. Setae dark red-brown, smooth, 6-8 mm long. Capsules erect, short-obloid, $1 \mathrm{~mm}$ long, dark, red-brown; exothecial cells at mouth red-brown, quadrate, uniformly thickened, at base short rectangular, yellowish brown, vertical walls thickened; phanerophore stomata at base; peristome teeth 8 , short, fragile, flat, trabeculae faint, smooth, median line on dorsal and ventral surface. Opercula rostrate, $0.8 \mathrm{~mm}$ long, beak erect; Calyptra cucullate, smooth, yellow with dark red tip, $1 \mathrm{~mm}$ long. Spores round, yellow-green, weakly granulate, $15-18 \mu \mathrm{m}$ in diameter.

\section{REFERENCES}

ALlen B. 1994. Moss Flora of Central America. Part 1. Sphagnaceae-Calymperaceae. Monogr. Syst. Bot. Missouri Bot. Gard. 49: 1-242.

Born S., FRAHM J.-P. \& PÓcs T. 1993. Taxonomic Results of the BRYOTROP Expedition to Zaire and Rwanda. 26. A new checklist of the mosses of Central Africa. Trop. Bryol. 8: 223-273.

Demaret F. 1940. Prodrome des Bryophytes du Congo Belge et du Ruanda-Urundi. I. Musci. Bull. Jard. Bot. État Bruxelles 16(1): 21-104.

MagiLl R. E. 1981. Flora of Southern Africa. Bryophyta. Part 1 Mosses. Fascicle 1. Sphagnaceae-Grimmiaceae. Botanical Research Institute, Pretoria.

Naveau R. 1927. Musci Bequaerti. Bull. Soc. Roy. Bot. Belgique 60(1): 11-56. 